\title{
Influence of the storage environment on the physiological quality of millet seeds (Pennisetum glaucum (L.) R. Br.) ${ }^{1}$
}

\author{
Girlânio Holanda da Silva ${ }^{2 *}$ (D), Mariana Zampar Toledo ${ }^{3}$, Renake Nogueira \\ Teixeira $^{4}$, Rubiana Falopa Rossi ${ }^{5}$, João Nakagawa ${ }^{2}$
}

\begin{abstract}
Millet is a species of the grass family used in cattle pastures, for hay, for silage, and in soil cover in notillage systems. However, studies on seed production and post-harvest techniques for this species have not been sufficiently developed, considering the demand for and potential of this crop. The objective of this study was to monitor the physiological quality of millet seeds stored in porous packaging. Millet seeds were stored under four ambient conditions (natural laboratory environment, dry chamber, refrigerator, and freezer). Physiological quality was evaluated by germination and vigor tests before and during storage each year, up to six years for the dry chamber and natural laboratory environment, and up to 12 years for the refrigerator and freezer. Analysis of variance was conducted on the data, which were in $4 \times 6$ and $2 \times 12$ (environment and storage period) factorial arrangements. The means of the environments were compared by the Tukey test $(p \leq 0.05)$ and the storage periods by regression analysis. The germination capacity of millet seeds is best conserved in a refrigerator and freezer, and they remain viable for up to twelve years of storage under these conditions.
\end{abstract}

Index terms: germination, conservation, physiological quality.

\section{Influência do ambiente de armazenamento na qualidade fisiológica de sementes de milheto (Pennisetum glaucum (L.) R. Br.}

\begin{abstract}
RESUMO - O milheto é uma espécie da família das gramíneas, utilizada na produção de pastagens para bovinos, feno, silagem e na cobertura do solo em sistema de plantio direto. No entanto, estudos sobre produção de sementes e técnicas de pós-colheita para esta espécie são incipientes considerando-se a demanda e o potencial desta cultura. Diante disso, objetivou-se monitorar a qualidade fisiológica de sementes de milheto armazenadas em embalagem porosa. As sementes de milheto foram armazenadas em quatro condições ambientais (ambiente natural de laboratório, câmara seca, geladeira e freezer). A qualidade fisiológica foi avaliada pelos testes de germinação e vigor antes e durante o armazenamento, anualmente, até 6 anos para o ambiente de câmara seca e de ambiente natural de laboratório e até 12 anos para geladeira e freezer. Os dados foram submetidos à análise de variância e analisados em esquema fatorial 4 × 6 e 2 × 12 (ambiente e período de armazenamento), com médias de ambientes comparadas pelo teste de Tukey ( $\mathrm{p} \leq 0,05)$ e períodos de armazenamento por análise de regressão. A capacidade germinativa das sementes de milheto é mais bem conservada em geladeira e freezer, permanecendo viáveis por até doze anos de armazenamento, nestas condições.
\end{abstract}

Termos para indexação: germinação, conservação, qualidade fisiológica.

\section{Introduction}

Pearl millet (Pennisetum glaucum) is an annual cycle species from the tropical climate of the Poaceae family used in production of pasture for bovines and as soil cover in no-tillage

${ }^{1}$ Submitted on 07/17/2018. Accepted for publication on: 04/01/2019. ${ }^{2}$ Departamento de Produção e Melhoramento Vegetal, FCA-UNESP, 18610-034 - Botucatu, SP, Brasil.

${ }^{3}$ Faculdade de Ciências Agrárias, FCA/UFGD, 79804-970 - Dourados, MS, Brasil. systems; it is also used as a green manure crop and for hay and silage. In various regions of the world, it is grown for grain production (Landau and Pereira-Filho, 2016; Mi et al., 2017). Millet seeds are important for maintaining and expanding the areas growing this grain and forage crop (Scheffer et al., 1985);

${ }^{4}$ Laboratory of Plant Physiology, Wageningen University, Droevendaalsesteeg 1, PB 6708 - Wageningen, Holanda.

${ }^{5}$ Departamento de Produção e Desenvolvimento Vegetal, Unidade Remota de Tapurah, 78555-000 - Tapurah, MT, Brasil.

*Corresponding author < girlanio_holanda@hotmail.com> 
yet there are no conclusive studies in the literature regarding the length of time and/or conditions under which these seeds can be stored for the purpose of conserving maximum vigor and retarding the effects of natural deterioration.

The germination capacity of seeds tends to diminish under storage, which may be accentuated or not depending on the conditions of temperature and relative humidity of the storage environment. After harvest, the deterioration process may advance until all the seeds lose their viability. Thus, the implications arising from data collected during the storage of seeds from important crops like millet enhance knowledge regarding the mechanisms that govern loss in vigor of these seeds, and this knowledge can be used for better conservation of the species (Nguyen et al., 2015).

Therefore, the challenge arises of seeking to ensure that all areas be planted with seeds of a high standard of physiological, physical, genetic, and sanitary quality (Santos et al., 2016), especially for millet, which has not been the focus of many studies regarding conservation of seeds during storage (Bahry et al., 2008).

The length of time in storage that seeds can maintain their capacity to germinate is crucial for any species. Knowledge of the main seed characteristics regarding the manner of storage is fundamental for conservation, and moisture content, temperature, and relative humidity are the main factors (Toledo et al., 2013; Umarani et al., 2015; Rocha et al., 2017; Venial et al., 2017; Silva et al., 2018). Knowledge of these factors that affect seed quality can make longer storage periods possible, allowing seeds to be used for sowing at different times of the year (Tombolato et al., 2009; Silva et al., 2015; Souza et al., 2016; Rocha et al., 2017).

With all these aspects in mind, the aim of this study was to assess the physiological quality of millet seeds over the time of storage.

\section{Material and Methods}

Millet (Pennisetum glaucum (L.) R. Br) seeds of the cv. BN-2, produced in Botucatu, SP, Brazil, were manually harvested and threshed on May 10, 2002. They were then dried and packaged in single-layer paper bags and placed under four storage environment conditions. The storage conditions were as follows: the natural laboratory environment (without control of relative humidity and temperature), dry chamber (40-50\% relative humidity without temperature control), refrigerator $(10-15 \%$ relative humidity and temperature from 5 to $\left.7{ }^{\circ} \mathrm{C}\right)$, and a "Frost Free" freezer $(48-52 \%$ relative humidity and temperature from -18 to $-22^{\circ} \mathrm{C}$ ).

Before storage, the seeds were characterized by 1000 seed weight, moisture content, and germination. Evaluations were made one month (year zero) after the beginning of the storage period in annual intervals beginning in July 2003 through determination of moisture content, germination percentage, and seed vigor.

The 1000 seed weight was evaluated before storage, using eight replications of 100 seeds, following the method of the Rules for Seed Testing (Brasil, 2009).

Moisture content was determined by the laboratory oven method at $105{ }^{\circ} \mathrm{C} \pm 3{ }^{\circ} \mathrm{C}$ for 24 hours, with two replications (Brasil, 2009) of approximately 2 to $3 \mathrm{~g}$ of seeds.

The germination test was performed with four replications of 100 seeds, sown in germination paper (PR) previously moistened with water in the amount of two and a half times the weight of the dry paper in a B.O.D. germinator, at a temperature of $20-30{ }^{\circ} \mathrm{C}$, with counting of normal seedlings at three and seven days after sowing (Brasil, 2009). In the final count, normal and abnormal seedlings and germinated and ungerminated seeds were determined (Brasil, 2009), and their respective percentages were calculated (Nakagawa et al., 1991). The first count of the germination test was considered as the indicator of seed vigor.

The assessments of seeds stored in the natural laboratory environment and in the dry chamber were made up to six years, because after that period there was infestation of the seeds by storage pests, and reliable dada could not be obtained. In the refrigerator and freezer environments, the assessments continued up to 12 years, when they ended for lack of material.

A completely randomized experimental design was used on the data from the germination test in $4 \times 6$ (four environments and six years of storage) and $2 \times 12$ (freezer and refrigerator environments and twelve years of storage) factorial arrangements, with four replications. Analysis of variance was conducted on the data. The mean values in reference to the storage environments were compared by the Tukey test ( $p \leq 0.05$ ), considering up to six or twelve years, and those of storage time by regression analysis for each storage environment - considering six years for the dry chamber and natural laboratory environment and twelve years for the refrigerator and freezer.

\section{Results and Discussion}

The millet seeds had a 1000 seed weight of $5.4 \mathrm{~g}$, moisture content of $12.5 \%$, and germination of $66 \%$ in determinations made before storage. After a month of storage under ambient (natural laboratory), dry chamber, refrigerator, and freezer conditions, the moisture contents were $10.5 \%, 10.6 \%, 8.2 \%$ and $12.1 \%$, and germination was $97 \%, 96 \%, 93 \%$ and $91 \%$, respectively, showing modification in moisture content and 
increases in germination due to dormancy release of newly harvested seeds (Oliveira et al., 2011; Toledo et al., 2013).

Dormancy release after physiological maturity is an event controlled by various factors, resulting from changes in temperature and moisture content of the seeds, which trigger changes in hormones like ABA, phenolic compounds, and proteins in the seeds, and dormancy can be overcome (Nakagawa et al., 2004; Née et al., 2017; Bian et al., 2018).

The data on moisture content of the seeds stored in the four different environments for the period of six years in the natural laboratory environment and dry chamber and for twelve years in the refrigerator and freezer are shown in Table 1. The moisture contents varied in the different environments due to the seeds being stored in porous packaging, which facilitates hygroscopic equilibrium in accordance with relative humidity (Toledo et al., 2007; Toledo et al., 2013; Costa et al., 2015). The seeds stored in the different environments had mean moisture contents of 9.9, 9.7, 5.9 and $13.2 \%$ for the natural laboratory environment, dry chamber, refrigerator, and freezer, respectively.

Storage conditions contribute to maintaining the quality of seeds up to the time of their use. Therefore, the ambient conditions related to high temperature, relative humidity, and seed moisture content must be observed before storage, since unfavorable conditions lead to accelerated reduction in seed longevity (Suriyong et al., 2015).

Among the previously cited factors, seed moisture content is considered the main factor that affects seed longevity because it can induce a high respiratory rate and consumption of energy reserves, and this is one of the main characteristics to be observed (Martins and Camargo, 2014; Wang et al., 2018). Ullmann et al. (2018) and Zucareli et al. (2015) in studies on sorghum and carioca common bean, respectively, observed that seeds of these species stored with a higher moisture content deteriorate more rapidly, suggesting that moisture content is a factor that may considerably affect seed longevity. In contrast, in the present study, the seed moisture content in each environment over the storage period showed small changes, therefore indicating that the moisture content may not have been the most influential factor in maintaining the physiological quality of the seeds (Nakagawa et al., 2004).

Nevertheless, it should be remembered that under natural ambient conditions, there is variation in relative humidity throughout the year, with consequent activity in seed moisture content, whereas in the other storage conditions, variation is minimal. In the city of Botucatu, where the experiment was conducted, the lowest relative humidities occur in July, when assessments were made, which explains the lower moisture contents of the seeds stored in the natural laboratory environment (Table 1).
According to the germination data, there was significant interaction between the environment and the seed storage period from zero up to six years for the percentage of germination and first count of germination; then, statistical unfolding was performed (Table 2). The dry chamber and natural laboratory environment were not favorable for storage since after the period of six years, insect attack occurred in the seed lots stored in those environments, and only the seeds of the refrigerator and freezer environments were left, which remained for up to 12 years. This occurrence indicates the need for more rigorous, preventive, and continuous control of storage pests when seeds are stored in porous packaging in a dry chamber and in a natural laboratory environment.

In addition, in the freezer, under the temperature from -18 to $-22{ }^{\circ} \mathrm{C}$, there were higher percentages of ungerminated millet seeds over the storage period of up to six years (Table 3 ). These results corroborate those of Bessa et al. (2015), who found the same response in crambe seeds.

The results of germination and of first count of germination and of the decompositions of the interaction between the environments and the storage periods are shown in Table 2. In general, the freezer and refrigerator environments were those that provided the best conditions for seed conservation for a period of up to six years. In contrast, in the natural laboratory environment and in the dry chamber there was a decline in mean values $(p \leq 0.05)$ as storage time advanced, for both the germination and first count of germination variables.

Table 1. Moisture content (\%) of millet seeds stored for up to six or twelve years in different environments.

\begin{tabular}{ccccc}
\hline \multirow{2}{*}{$\begin{array}{c}\text { Time } \\
\text { (years) }\end{array}$} & $\begin{array}{c}\text { Satural laboratory } \\
\text { environment }\end{array}$ & $\begin{array}{c}\text { Dry } \\
\text { chamber }\end{array}$ & Refrigerator & Freezer \\
\hline 0 & 10.5 & 10.6 & 8.2 & 12.1 \\
1 & 10.3 & 9.0 & 6.2 & 13.8 \\
2 & 10.3 & 9.9 & 5.4 & 13.6 \\
3 & 10.2 & 8.4 & 5.5 & 13.8 \\
4 & 9.5 & 10.0 & 5.9 & 13.8 \\
5 & 9.6 & 9.7 & 5.7 & 13.4 \\
6 & 9.0 & 10.6 & 4.9 & 11.8 \\
7 & - & - & 5.0 & 11.6 \\
8 & - & - & 7.1 & 14.0 \\
9 & - & - & 4.7 & 13.8 \\
10 & - & - & 5.4 & 14.3 \\
11 & - & - & 9.2 & 14.0 \\
12 & - & - & 4.0 & 11.7 \\
\hline Means & 9.9 & 9.7 & 5.9 & 13.2 \\
\hline
\end{tabular}


Table 2. Decomposition of the interactions for mean percentages of germination and of first count of germination (FC) of millet seeds stored for six years in different environments.

\begin{tabular}{|c|c|c|c|c|}
\hline & \multicolumn{4}{|c|}{-----------------------Environments------------------------ } \\
\hline & $\begin{array}{c}\text { Natural laboratory } \\
\text { environment }\end{array}$ & $\begin{array}{c}\text { Dry } \\
\text { chamber }\end{array}$ & Refrigerator & Freezer \\
\hline Years & \multicolumn{4}{|c|}{ 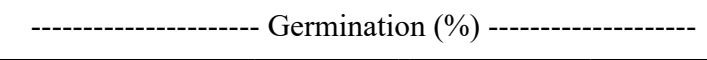 } \\
\hline 0 & $97 \mathrm{a}$ & $96 \mathrm{a}$ & $93 \mathrm{a}$ & $91 \mathrm{a}$ \\
\hline 1 & $91 \mathrm{a}$ & $94 \mathrm{a}$ & $91 \mathrm{a}$ & $90 \mathrm{a}$ \\
\hline 2 & $94 \mathrm{a}$ & $93 \mathrm{a}$ & $90 \mathrm{a}$ & $88 \mathrm{a}$ \\
\hline 3 & $92 \mathrm{a}$ & $94 \mathrm{a}$ & $92 \mathrm{a}$ & $81 \mathrm{~b}$ \\
\hline 4 & $93 \mathrm{a}$ & $95 \mathrm{a}$ & $92 \mathrm{a}$ & $88 \mathrm{a}$ \\
\hline 5 & $87 \mathrm{a}$ & $88 \mathrm{a}$ & $89 \mathrm{a}$ & $91 \mathrm{a}$ \\
\hline 6 & $77 \mathrm{~b}$ & $87 \mathrm{a}$ & $92 \mathrm{a}$ & $89 \mathrm{a}$ \\
\hline \multicolumn{5}{|c|}{ - } \\
\hline 0 & $96 \mathrm{a}$ & $95 \mathrm{a}$ & 89 a & $89 \mathrm{a}$ \\
\hline 1 & $91 \mathrm{a}$ & $93 \mathrm{a}$ & $87 \mathrm{~b}$ & $85 \mathrm{a}$ \\
\hline 2 & $90 \mathrm{a}$ & $88 \mathrm{a}$ & $79 \mathrm{~b}$ & $78 \mathrm{~b}$ \\
\hline 3 & $87 \mathrm{a}$ & $90 \mathrm{a}$ & $85 \mathrm{a}$ & $72 b$ \\
\hline 4 & $90 \mathrm{a}$ & $93 \mathrm{a}$ & $85 \mathrm{ab}$ & $77 \mathrm{~b}$ \\
\hline 5 & $82 \mathrm{a}$ & $83 \mathrm{a}$ & $84 \mathrm{a}$ & $84 \mathrm{a}$ \\
\hline 6 & $75 \mathrm{~b}$ & $82 \mathrm{ab}$ & $91 \mathrm{a}$ & $85 \mathrm{a}$ \\
\hline
\end{tabular}

* Mean values followed by the same letters in the same row do not differ statistically by the Tukey test at $5 \%$ probability.

The results of assessment of physiological quality of the seeds stored under the different conditions are shown in Figure 1 by percentage of germinated seeds (A), of first count of germination (B), and of ungerminated seeds (C). These results show that the storage conditions of the natural laboratory environment and of the dry chamber were harmful to seed physiological quality as storage time advanced, and the greatest reduction was found for the natural laboratory environment, as seen by the greater slope of the curves (Figures 1A and 1B). The percentages of ungerminated seeds (Table 2, Figure 1C) during the storage period also show the worse storage condition of the natural laboratory environment, and the results of the germination test as well.

Based on these results shown in Figure 1 and Table 2, two groups with different environmental conditions can be considered to assess the effects of temperature and of relative humidity on seed physiological quality. The dry chamber and the natural laboratory environment have similar conditions of temperature variables, whereas for relative humidity, the dry chamber is more stable throughout the entire storage period, with lower oscillations in seed moisture content, resulting in
Table 3. Mean percentages of abnormal seedlings (AS) and of ungerminated seeds (US) of millet according to storage time and environment.

\begin{tabular}{ccc}
\hline Treatment & AS $^{(1)}$ & US $^{(1)}$ \\
\hline Storage time & $0^{*}$ & $5^{*}$ \\
\hline 0 & 1 & 8 \\
2 & 1 & 4 \\
3 & 3 & 5 \\
4 & 2 & 6 \\
5 & 3 & 8 \\
6 & 3 & 11 \\
\hline Storage environment ${ }^{(2)}$ & & $7 \mathrm{ab}$ \\
\hline Environment & $2^{\text {ns }}$ & $5 \mathrm{~b}$ \\
Dry chamber & 2 & $6 \mathrm{ab}$ \\
Refrigerator & 2 & $9 \mathrm{a}$ \\
Freezer & 2 & $\mathrm{~ns}$ \\
Interaction & $\mathrm{ns}$ & 10.39 \\
\hline C.V. (\%) & 10.69 &
\end{tabular}

${ }^{(1)}$ Data transformed in arcsine $(\mathrm{x} / 100)+0.5$ for statistical analysis; mean values shown are from the original data.

${ }^{(2)}$ Mean values followed by the same letter in the column for comparison of storage environments do not differ statistically by the Tukey test $(\mathrm{p} \leq 0.05)$. ns $=$ not significant.

* and $* *$ significant at $5 \%$ and $1 \%$ probability, respectively.

better conservation of physiological quality.

The refrigerator and freezer environment have temperature and relative humidity conditions with small oscillations, which was confirmed by the moisture content of the seeds during the storage period (Table 1). The low relative humidity, from 10 to $15 \%$, maintained in the refrigerator environment, although with higher temperature, from 5 to $7{ }^{\circ} \mathrm{C}$, contributed to better physiological quality of the seeds after six years of storage, compared to the seeds stored in the freezer, at lower temperatures.

These results corroborate those obtained for sudangrass (Sorghum sudanense) seeds, in which the refrigerator and freezer environments, followed by the dry chamber, led to more adequate conservation than the natural laboratory environment, which had faster loss of vigor (Toledo et al., 2007; Toledo et al., 2013). In black oat seeds, the refrigerator and freezer environments were also more favorable for conservation than the dry chamber environment and natural environment (Nakagawa et al., 2004).

The mean data of percentage of first count of germination, of germination, and of germinated seeds are presented in Figure 2 and show the effect of the storage environment. For the 

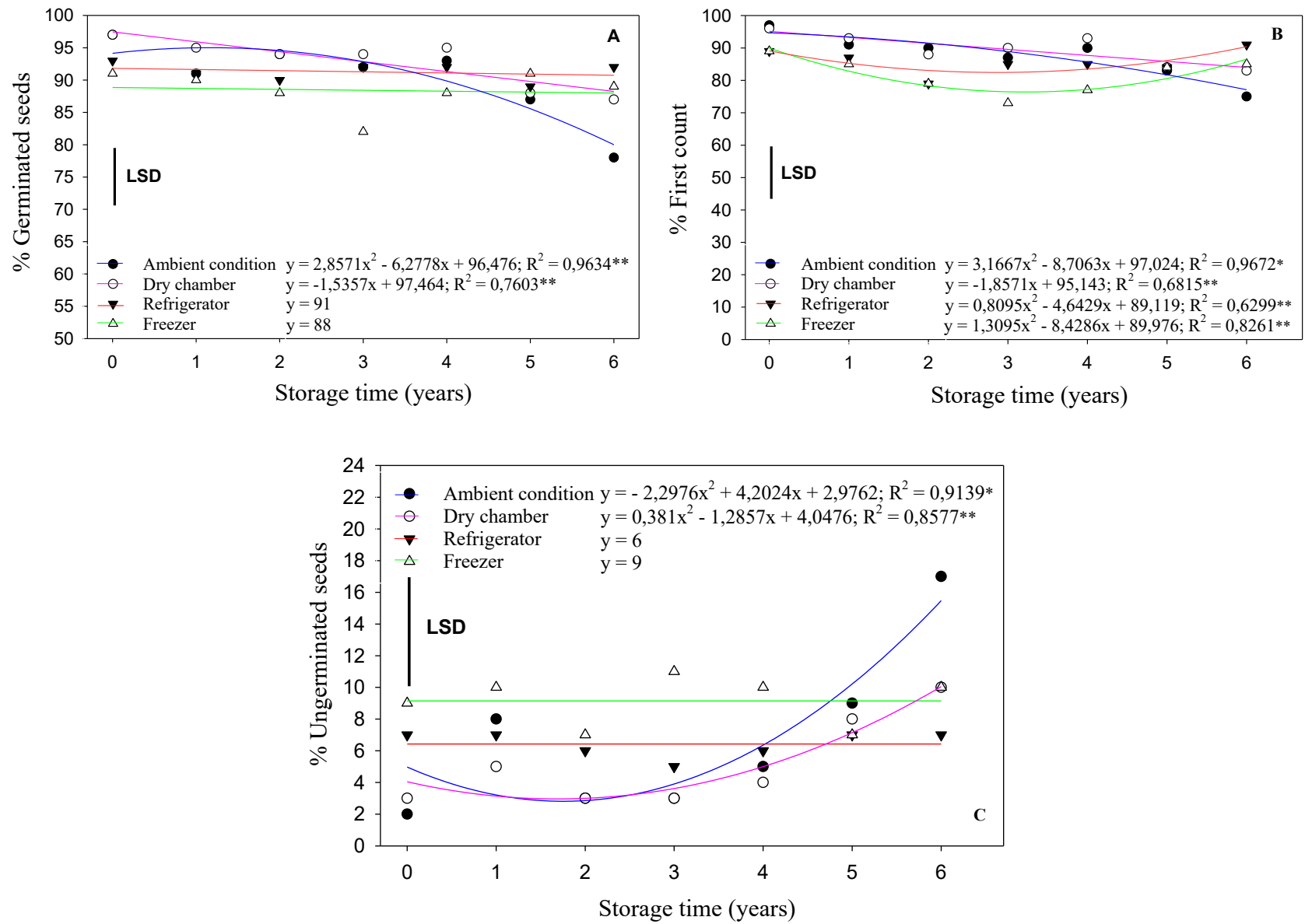

*and ** significant at $5 \%$ and $1 \%$ probability, respectively.

Vertical bars within the figures indicate the value of LSD (least significant difference).

Figure 1. Mean percentage of germination (A), first count of germination (B), and ungerminated seeds (C) of millet, stored for six years in different environments.
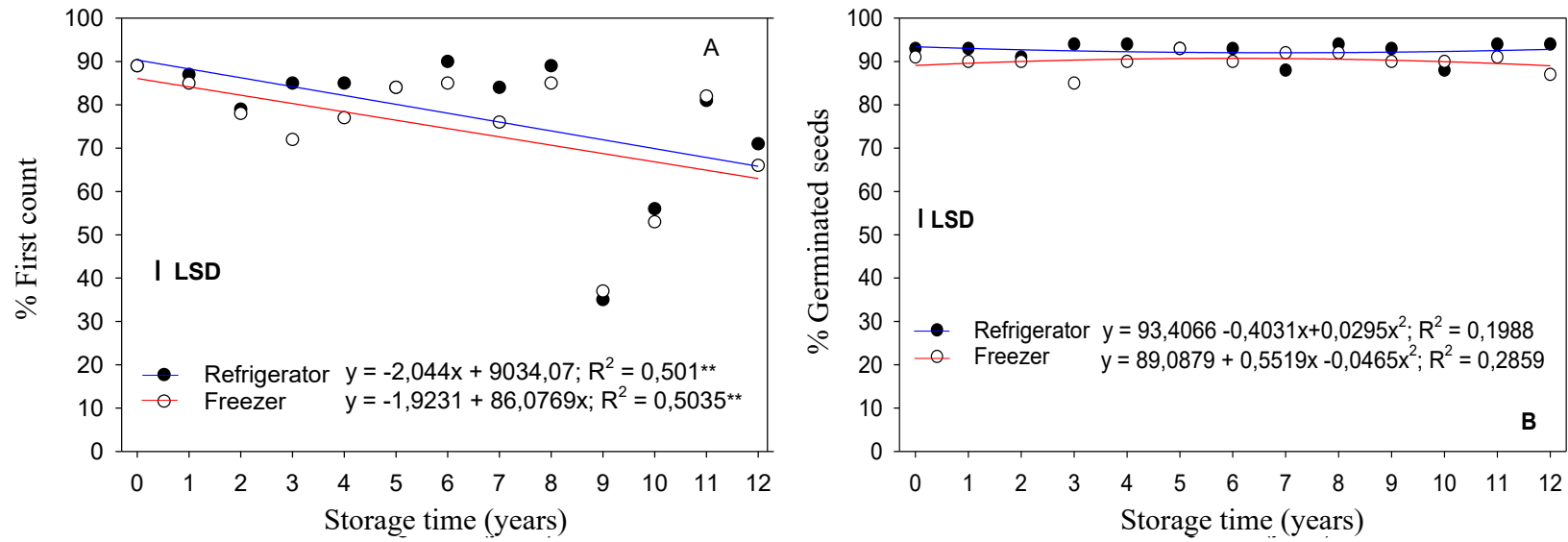

**Significant at $1 \%$ probability.

Vertical bars within the figures indicate the value of LSD (least significant difference).

Figure 2. Mean results of first count of germination (A) and germinated seeds (B) of millet according to storage time and environment. 
variables of first count of germination and germinated seeds, there was a linear and quadratic tendency, respectively, as observed in Figures 2A and 2B. The refrigerator environment best preserved the physiological quality of the seeds over time, with mean germination of $88 \%$ at 12 years.

In addition, over the years, in the freezer and refrigerator environments, the vigor index, analyzed by the first count of germination, decreases less sharply when storage begins (Figure 2B), corroborating other studies (Marcos-Filho, 2015; Silva et al., 2015).

Storage of millet seeds in a freezer or refrigerator environment makes it possible to conserve the physiological quality of millet seeds for 12 years, with germination percentages above the standard recommended for commercialization, which is $75 \%$ (Brasil, 2008). In addition, the seed moisture content and the temperature of these two environments were factors that had a positive effect during the storage period, manifesting the orthodox nature of the seeds. The temperatures in these environments may have contributed to reduce metabolic activity and respiratory rates in the seeds, which may favor maintenance of viability during this period (Garcia et al., 2014; Nardello et al., 2016).

The results obtained in this study also corroborate those found by Araújo Neto et al. (2005) in Acacia polyphylla DC seeds, by Borba Filho and Perez (2009) in Tabebuia impetiginosa DC seeds, and by Silva et al. (2015) with apple of Sodom (Calotropis procera WT), in which it was observed that the percentage of germination is more affected in the natural laboratory environment, where there is no control of temperature and relative humidity.

The results of this study confirm the effect of different storage conditions on the germination and vigor of millet seeds, as well as the need to choose an environment that allows seed physiological quality to be maintained for a longer period.

\section{Conclusions}

The germination of millet seeds is best conserved in the refrigerator and freezer environment, making storage possible for up to twelve years. The storage environments of the dry chamber and natural laboratory environment are less favorable for storage of millet seeds.

\section{References}

ARAÚJO NETO, J.C.D.; AGUIAR, I.B.D.; FERREIRA, V.M.; RODRIGUES, T.D.J.D. Armazenamento e requerimento fotoblástico de sementes de Acacia polyphylla Dc. Revista Brasileira de Sementes, v.27, n.1, p.115-124, 2005. http://www.scielo.br/pdf/\%0D/ rbs/v27n1/25188.pdf
BAHRY, C.A.; MUNIZ, M.F.B.; FRANZIN, S.M.; CASAROLI, D.; GARCIA, D.C.; ANTONELLO, L.M. Influência do armazenamento na qualidade fisiológica e sanitária de sementes de milheto. Pesquisa Agropecuária Gaúcha, v.14, n.1, p.119-124, 2008. http://www. fepagro.rs.gov.br/upload/1398791797_artigo_06.pdf

BESSA, J.F.; DONADON, J.R.; RESENDE, O.; ALVES, R.; SALES, F.J.; COSTA, E.L.M. Armazenamento do crambe em diferentes embalagens e ambientes: Parte I - Qualidade fisiológica. Revista Brasileira de Engenharia Agrícola e Ambiental - Agriambi, v.19, n.3, p.224-230, 2015. http://dx.doi.org/10.1590/1807-1929/ agriambi.v19n3p224-230

BIAN, F.; SU, J.; LIU, W.; LI, S. Dormancy release and germination of Taxus yunnanensis seeds during wet sand storage. Scientific Reports, v.8, n.1, 2018. https://www.nature.com/articles/s41598018-21469-9

BORBA FILHO, A.B.; PEREZ, S.C.J.G.A. Armazenamento de sementes de ipê-branco e ipê-roxo em diferentes embalagens e ambientes. Revista Brasileira de Sementes, v.31, n.1, p.259-269, 2009. http://www.scielo.br/pdf/rbs/v31n1/a29v31n1.pdf

BRASIL. Ministério da Agricultura, Pecuária e Abastecimento. Regras para análise de sementes. Ministério da Agricultura, Pecuária e Abastecimento. Secretaria de Defesa Agropecuária. Brasília: MAPA/ACS, 2009. 395p. http://www.agricultura.gov.br/assuntos/ insumos-agropecuarios/arquivos-publicacoes-insumos/2946_ regras_analise_sementes.pdf

BRASIL. Ministério da Agricultura, Pecuária e Abastecimento. Instrução Normativa $n^{\circ}$ 30. Padrões para comercialização de sementes de espécies forrageiras de clima tropical. Diário Oficial da União, $n^{\circ} 30$, seção 1,21 maio 2008. 16p.

COSTA, L.M.; RESENDE, O.; OLIVEIRA, D.E.C. Determinação das isotermas de equilíbrio higroscópico de frutos de crambe pelo método dinâmico. Bioscience Journal, v.31, n.2, p.382-391, 2015. http://www. seer.ufu.br/index.php/biosciencejournal/article/view/22337/16113

GARCIA, C.; COELHO, C.M.M.; MARASCHIN, M.; OLIVEIRA, L.M. Conservação da viabilidade e vigor de sementes de Araucaria angustifolia (Bert.) O. Kuntze durante o armazenamento. Ciência Florestal, v.24, n.4, p.857-867, 2014. https://periodicos.ufsm.br/ index.php/cienciaflorestal/article/viewFile/16586/pdf_1

LANDAU, E.C.; PEREIRA-FILHO, J.A. Cultivo do milheto. Embrapa Milho e Sorgo, p.3, 2016. https://ainfo.cnptia.embrapa.br/ digital/bitstream/item/27379/1/Clima.pdf

MARCOS-FILHO, J. Seed vigor testing: an overview of the past, present and future perspective. Scientia Agricola, v.72, n.4, p.363-374, 2015. http://www.scielo.br/pdf/sa/v72n4/0103-9016-sa-72-4-0363.pdf

MARTINS, C.C.; CAMARGO, M.A.D.S. Armazenamento de sementes de ipê-amarelo-do-brejo (Handroanthus umbellatus (Sond.) Mattos. Bignoniaceae). Ciência Florestal, v.24, n.3, p.533-539, 2014. http://www.redalyc.org/pdf/534/53432098002.pdf

MI, J.; GREGORICH, E.G.; XU, S.; MCLAUGHLIN, N.B.; MA, B.; LIU, J. Effect of bentonite amendment on soil hydraulic parameters and millet crop performance in a semi-arid region. Field Crops Research, v.212, p.107-114, 2017. http://dx.doi.org/10.1016/j.fcr.2017.07.009 
NAKAGAWA, J.; CAVARIANI, C.;AMARAL, W.A.N. Armazenamento de sementes de maracujá amarelo. Revista Brasileira de Sementes, v.13, n.1, p.77-80, 1991

NAKAGAWA, J.; CAVARIANI, C.; CASTRO, M.M. Armazenamento de sementes de aveia preta produzidas em solos de diferentes fertilidades. Revista Brasileira de Sementes, v.26, n.2, p.7-14, 2004. https://www.agrolink.com.br/downloads/123299.pdf

NARDELLO, I.C.; MELLO-FARIAS, P.; CHAVES, A.L.S.; PEIL, R.M.N. Viabilidade de sementes desidratadas de Lycium barbarum para formação de mudas. Revista da Jornada da Pós-Graduação e Pesquisa - Congrega Urcamp, p.1193-1203, 2016. http://trabalhos. congrega.urcamp.edu.br/index.php/jpgp/article/view/1110/1054

NÉE, G.; XIANG, Y.; SOPPE, W.J.J. The release of dormancy, a wake-up call for seeds to germinate. Current Opinion in Plant Biology, v.35, p.8-14, 2017. https://doi.org/10.1016/j.pbi.2016.09.002

NGUYEN, T.P.; CUEFF, G.; HEGEDUS, D.D.; RAJJOU, L.; BENTSINK, L. A role for seed storage proteins in Arabidopsis seed longevity. Journal of Experimental Botany, v.66, n.20, p.399-6413, 2015. https://doi.org/10.1093/jxb/erv348

OLIVEIRA, J.A.; SILVA, T.T.A.; VON PINHO, E.V.R.; ABREU, L.A.S. Secagem e armazenamento de sementes de sorgo com alto e baixo teor de tanino. Revista Brasileira de Sementes, v.33, n.4, p.699-710, 2011. http://submission.scielo.br/index.php/jss/article/view/38618/6768

ROCHA, G.C.; NETO, A.R.; CRUZ, S.J.S.; CAMPOS, G.W.B.; OLIVEIRA, C.A.C; SIMON, G.A. Qualidade fisiológica de sementes de soja tratadas e armazenadas. Cientific Multidisciplinary Journal, v.4, n.1, p.50-65, 2017. https://doi.org/10.29247/2358260X.2017v4i1.p50-65.

SANTOS, J.; MÜHL, F.R.; MOREIRA, A.; RITTER, A.F.S.; FELDMANN, N.A.; RHODEN, A.; BALBINOT, M. Avaliação da qualidade fisiológica e sanitária de sementes de soja produzidas no município de Frederico Westphalen/RS. Revista de Ciências Agroveterinárias e Alimentos, v.1, n.1, p.1-14, 2016. http://revista. faifaculdades.edu.br/index.php/cava/article/view/204/114

SCHEFFER, S.M.; SAIBRO, J.C.; RIBOLDI, J. Efeito do nitrogênio, métodos de semeadura e regime de corte no rendimento e qualidade da forragem e da semente de milheto. Pesquisa Agropecuária Brasileira, v.20, n.3, p.309-317, 1985. https://seer.sct.embrapa.br/ index.php/pab/article/view/15125/8900

SILVA, D.G.S.; CARVALHO, M.L.M.; NERY, M.C.N.; OLIVEIRA, L.M.; CALDEIRA, C.M.C. Alterações fisiológicas e bioquímicas durante o armazenamento de sementes de Tabebuia serratifolia. Cerne, v.17, n.1, p.1-7, 2015. http://www.cerne.ufla.br/site/index. php/CERNE/article/view/6/3

SILVA, S.R.; BARROS TORRES, S.R.; VIEIRA BENTO, D.A.; ALBUQUERQUE, S.B.K.; CARVALHO, D.F.J.; COSTA, M.V. Armazenamento de sementes de flor-de-seda [Calotropis procera (Aiton) WT Aiton]. Revista Caatinga, v.28, n.1, p.39-47, 2015. http://www.redalyc.org/pdf/2371/237138297005.pdf
SILVA, G.H.D.; JOSÉ, A.C.; FARIA, J.M.R. Behavior of Peltophorum dubium ((Spreng.) Taub.) seeds in a burial seed bank. Floresta e Ambiente, v.25, n.1, p.1-8, 2018. http://dx.doi. org/10.1590/2179-8087.013716

SOUZA, P.P.D.; MOTOIKE, S.Y.; CARVALHO, M.; KUKI, K.N.; SILVA, A.M. Storage on the vigor and viability of macauba seeds from two provenances of Minas Gerais State. Ciência Rural, v.46, n.11, p. 1932-1937, 2016. http://dx.doi.org/10.1590/0103-8478cr20150848

SURIYONG, S.; KRITTIGAMAS, N.; PINMANEE, S.; PUNYALUE, A.; VEARASILP, S. Influence of storage conditions on change of hemp seed quality. Agriculture and Agricultural Science Procedia, v.5, p.170-176, 2015. https://doi.org/10.1016/j.aaspro.2015.08.026

TOLEDO, M.Z.; CAVARIANI, C.; NAKAGAWA, J.; ALVES, E. Efeitos do ambiente de armazenamento na qualidade de sementes de sorgo-sudão. Revista Brasileira de Sementes, v.29, n.2, p.44-52, 2007. http://www.scielo.br/pdf/rbs/v29n2/v29n2a07

TOLEDO, M.Z.; CAVARIANI, C.; NAKAGAWA, J.; CORREA, E.A. Extended storage of sudangrass seeds. Revista Brasileira de Milho e Sorgo, v.12, n.3, p.326-365, 2013. https://ainfo.cnptia. embrapa.br/digital/bitstream/item/104578/1/Extended-storage.pdf

TOMBOLATO, A.F.C.; LUCON, T.N.; MOURA, M.F.; BARBOSA, W.; MONTEIRO-JÚNIOR, M.B.; SCHIAVINATO, Y.; VEIGA, R.F.A. Crioconservação de espécies de Amaryllidaceae. Ornamental Horticulture, v.15, n.1, p.149-154, 2009. https://doi.org/10.14295/ rbho.v15i1.438

ULLMANN, R.; RESENDE, O.; RODRIGUES, G.B.; CHAVES, T.H.; OLIVEIRA, D.E.C. Qualidade fisiológica das sementes de sorgo sacarino submetidas à secagem e ao armazenamento. Revista Engenharia na Agricultura, v.26, n.4, p.313-321, 2018. https://doi. org/10.13083/reveng.v26i4.960

UMARANI, R.; ADHAVAN, E.K.; FAISAL, M.M. Understanding poor storage potential of recalcitrant seeds. Current Science, v.108, n.11, p.2023-2034, 2015. http://citeseerx.ist.psu.edu/viewdoc/ download?doi=10.1.1.692.4581\&rep=rep1\&type=pdf

VENIAL, L.R.; ALEXANDRE, R.S.; CAMATA, H.; LOPES, J.C.; ZANOTTI, R.F.; FERREIRA, A.; AGUILAR, M.A.G. Biometria e armazenamento de sementes de genótipos de cacaueiro. Pesquisa Florestal Brasileira, v.37, n.89, p.39-46, 2017. https://doi. org/10.4336/2017.pfb.37.89.1239

WANG, W.; HE, A.; PENG, S.; HUANG, J.; CUI, K.; NIE, L. The effect of storage condition and duration on the deterioration of primed rice seeds. Frontiers in Plant Science, v.9, 2018. https://doi: $10.3389 /$ fpls. 2018.00172

ZUCARELI, C.; BRZEZINSKI, C.R.; ABATI, J.; WERNER, F.; RAMOS-JÚNIOR, E.U.; NAKAGAWA, J. Qualidade fisiológica de sementes de feijão carioca armazenadas em diferentes ambientes. Revista Brasileira de Engenharia Agrícola e Ambiental - Agriambi, v.19, n.8, p.803-809, 2015. http://dx.doi.org/10.1590/1807-1929/ agriambi.v19n8p803-809 